\title{
Analisis Pengaruh Tingkat Pendidikan, Keterampilan, Tingkat Pendapatan Dan Tanggungan Keluarga Terhadap Kemiskinan Di Desa Mas-Mas Kecamatan Batukliang Utara Kabupaten Lombok Tengah
}

\author{
${ }^{1}$ Rohaeniah Zein, ${ }^{2}$ Siti Raehanun \\ 1,2, Prodi pendidikan ekonomi, FISE Universitas Hamzanwadi \\ Email: rohaeniahzain@gmail.com
}

Received: 15 Januari, 2019; Accepted: 25 Maret, 2019; Published: 25 Juni, 2019

\begin{abstract}
Abstrak
Tujaun dalam penelitian ini adalah Untuk mengetahui pengaruh tingkat pendidikan, keterampilan, tingkat pendapatan dan tanggungan keluarga secara simultan terhadap kemiskinan di Desa Mas-Mas Kecamatan Batukliang Utara Kabupaten Lombok Tengah. Untuk mengetahui pengaruh tingkat pendidikan, keterampilan, tingkat pendapatan dan tanggungan keluarga secara parsial terhadap kemiskinan di Desa Mas-Mas Kecamatan Batukliang Utara Kabupaten Lombok Tengah. Jenis penelitian ini adalaha penelitian kuantitatif, Tehnik sampling yang digunakan dalam penelitian ini menggunakan proporsional sampling Adapun tehnik pengumpulan data yang digunakan yakni dengan menggunakan Kuesioner dan dokumentasi

Hasil penelitian menunjukkan bahwa Secara simulltan, pengaruh tingkat pendidikan, keterampilan, tingkat pendapatan dan tanggungan keluarga berpengaruh secara simultan atau bersama-sama terhadap kemiskinan di Desa Mas-Mas. Hal ini terbukti dari nilai $F_{\text {hitung }}>F_{\text {tabel }}(3,475>2,48)$. Besarnya pengaruh keempat variabel terhadap kemiskinan di Desa Mas-Mas ditunjukkan dengan $R$ Square yaitu sebesar 0,138 atau $13,8 \%$ dan sisanya $86,2 \%$ depengaruhi oleh variabel lain yang tidak termasuk dalam penelitian ini. Korelasi ganda secara serentak menunjukkan bahwa terjadi hubungan yang rendah antara tingkat pendidikan, keterampilan, tingkat pendapatan dan tanggungan keluarga terhadap kemiskinan di Desa Mas-Mas Kecamatan Batukliang Utara Kabupaten Lombok Tengah pada tahun 2019. Secara parsial, variabel tingkat pendidikan dan keterampilan tidak memiliki pengaruh yang signifikan terhadap kemiskinan di Desa Mas-Mas. Hal tersebut dapat dilihat dari nilai $t_{\text {hitung }}<t_{\text {tabel }} \quad(0,196<1,98$ dan $1,514<1,98)$. Sedangkan variabel tingkat pendapatan memiliki pengaruh yang positif dan signifikan terhadap kemiskinan di Desa Mas-Mas. Hal tersebut dapat dilihat dari nilai $t_{\text {hitung }}>\mathrm{t}_{\text {tabel }}(2,689>1,98)$ dan begitupun dengan variabel tanggungan keluarga memiliki pengaruh yang negatif dan signifikan terhadap kemiskinan di Desa Mas-Mas. Hal tersebut dapat dilihat dari nilai $-\mathrm{t}_{\text {hitung }}>-\mathrm{t}_{\text {tabel }}(-$ $2,614>-1,98)$

Kata kunci : Kemiskinan, Keterampilan, Tanggungan Keluarga, Tingkat Pendapatan, Tingkat Pendidikan
\end{abstract}




\begin{abstract}
The purpose of this study was to determine the effect of education level, skills, income level and family dependency simultaneously on poverty in Mas-Mas Village, North Batukliang District, central Lombok Regency. To determine the effect of education level, skills, income level and partial family dependence on poverty in Mas-Mas Village, North Batukliang District, Central Lombok Regency. This type of research is quantitative research, the sampling technique used in this study uses proportional sampling The data collection techniques used are using questionnaires and documentation

The results of the study show that simulltan influences the level of education, skills, income level and family dependency simultaneously or jointly on poverty in Mas-Mas Village. This is evident from the value of Fcount> Ftable $(3,475>2,48)$. The magnitude of the influence of the four variables on poverty in Mas-Mas Village is shown by R Square which is equal to 0.138 or $13.8 \%$ and the remaining $86.2 \%$ is affected by other variables not included in this study. Multiple correlations simultaneously indicate that there is a low correlation between education level, skills, income level and family dependence on poverty in MasMas Village, North Batukliang Subdistrict, Central Lombok Regency in 2019. Partially, the education and skill level variables have no influence significant impact on poverty in Mas-Mas Village. This can be seen from the value of tcount $<$ t table $(0.196<1.98$ and $1.514<1.98)$. While income level variables have a positive and significant effect on poverty in Mas-Mas Village. This can be seen from the tcount $>t$ table $(2.689>1.98)$ and so with the family dependent variable has a negative and significant effect on poverty in Mas-Mas Village. This can be seen from the value of -thitung $>$-ttable $(-2,614>-1,98)$

Keywords: Education Level, Family Dependency, Income Level, Poverty, Skills.
\end{abstract}

\title{
PENDAHULUAN
}

Kemiskinan di indonesia masih menjadi masalah yang serius sejak era pasca kemerdekaan hingga saat ini. Pengukuran kemiskinan di ndonesia dilakukan oleh Badan Pusat Statistik (BPS) dengan menggunakan konsep kemampuan memenuhi kebutuhan dasar (basic needs approach). Menurut BPS kemiskinan dipandang sebagai ketidak mampuan dari sisi ekonomi untuk memenuhi kebutuhan dasar makanan dan bukan makanan dengan pendekatan pengeluaran. Penduduk dikatakan miskin apabila memiliki rata-rata pengeluaran perkapita perbulan dibawah garis kemiskinan. Menurut BPS pula bahwa kemiskinan adalah kondisi seseorang yang hanya mampu memenuhi kebutuhan makanannya kurang dari 2.100 kalori perkapita perhari.

Jumlah penduduk miskin antar provinsi di indonesia berbeda-beda, yang menjadi sorotan adalah jumlah penduduk miskin provinsi Nusa Tenggara Barat (NTB). Angka kemiskinan di NTB saat ini tergolong masih cukup tinggi, 
Karena NTB masuk dalam 8 besar provinsi berpenduduk miskin terbanyak dari 34 provinsi di indonesia pada tahun 2016.

Kabupaten Lombok Tengah merupakan salah satu daerah yang ada di Nusa Tenggara Barat (NTB) yang memiliki potensi alam yang cukup besar. Mulai dari lahan pertanian hingga kawasan pantai yang membentang luas. Lombok tengah juga merupakan sektor wisata unggulan di NTB. Tetapi jumlah penduduk kategori miskin di Lombok Tengah masih tinggi. Masih banyak penduduk yang tidak dapat memenuhi kebutuhan makan mereka secara maksimal. Hal tersebut dapat dikarenakan pendapatan yang mereka miliki tidak cukup untuk memenuhi kebutuhan. Kemiskinan disebabkan karena adanya kesenjangan pendapatan antar masyarakat.

Tabel 1.2 Jumlah Penduduk Miskin di Kabupaten Lombok

Tengah

\begin{tabular}{ccc}
\hline & \multicolumn{2}{c}{ Penduduk Miskin } \\
Tahun & \multicolumn{2}{c}{ Number Of Poor People } \\
Year & Total & $\begin{array}{c}\text { Persentase } \\
\text { Percentage }\end{array}$ \\
\cline { 2 - 3 } & $(2)$ & $(3)$ \\
\hline$(1)$ & 147.940 & 16,26 \\
2015 & 145.370 & 15,80 \\
2016 & 142.140 & 15,31 \\
2017 & 118.010 & 13,87 \\
\hline Sumber: BPS Lombok Tengah & & \\
\hline
\end{tabular}

Berdasarkan tabel diatas terlihat bahwa jumlah penduduk miskin di Lombok Tengah mengalami penurunan selama empat tahun terakhir. Pada tahun 2017 jumlah penduduk miskin sebanyak 142.140 jiwa atau 15,31\% dari total penduduk Kabupaten Lombok Tengah. Sedangkan pada tahun 2018 
memiliki jumlah penduduk miskin sebanyak 118.010 jiwa atau 13,87\% dari total penduduk Kabupaten Lombok Tengah. Jika dibanding tahun 2017 jumlah penduduk miskin di Kabupaten Lombok Tengah mengalami penurunan yang signifikan selama empat tahun terakhir yaitu sebesar 1,44\%. Meskipun Lombok Tengah mengalami penurunan persentasi yang begitu signifikan, tetapi penduduk miskin di Kabupaten Lombok Tengah masih diatas 10\%.

Desa Mas-Mas Kecamatan Batukliang Utara memiliki jumlah penduduk 6.505 penduduk dengan jumlah kepala keluarga 2.091 kepala keluarga. Sedangkan jumlah kemiskinan di desa tersebut sebesar 1.085 kepala keluarga. Berarti, jumlah kepala keluarga miskin lebih besar daripada jumlah kepala keluarga tidak miskin. Hal tersebut disebabkan karena pendapatan yang rendah akibat rendahnya produktifitas dan keterampilan, sarana produksi yang digunakan masih sederhana, pendidikan rendah dan tanggungan keluarga tinggi.

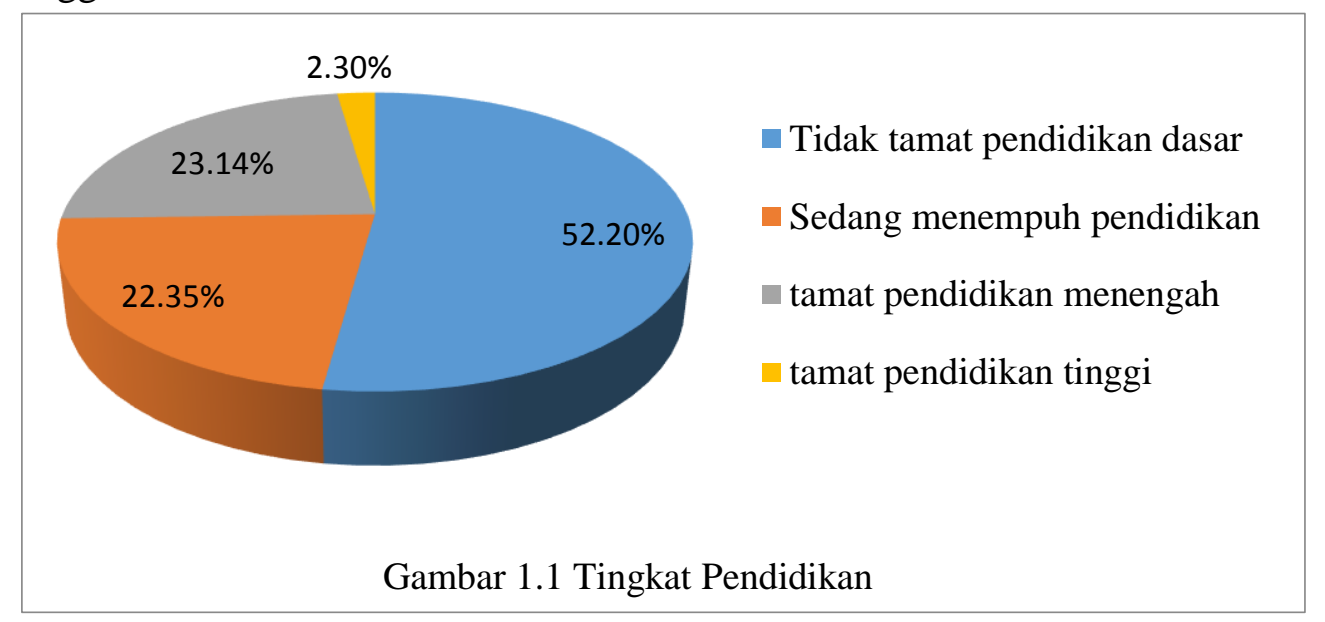

Sumber: Data Desa Mas-Mas 2018.diolah

Berdasarkan gambar di atas bahwa tingkat pendidikan di Desa Mas-Mas masih rendah dilihat dari persentasi banyaknya penduduk yang tidak tamat pendidikan dasar (SD dan SMP sederajat) sebanyak 52,20\% atau setara dengan 2.519 penduduk. Padahal sistem pendidikan nasional mewajibkan setiap warga negara yang berusia 7 sampai 15 tahun wajib mengikuti pendidikan dasar secara gratis. Hal tersebut telah dijelaskan dalam Undang-Undang Dasar RI 
1945 pasal 31 ayat 2 menyebutkan bahwa setiap warga negara wajib mengikuti pendidikan dasar dan pemerintah wajib membiayainya. Karena dengan adanya pendidikan masyarakat diharapkan dapat mempunyai keterampilan.

Keterampilan masyarakat yang ada di desa Mas-Mas beragam, seperti mengetak, membuat kripik bonggol pisang, dan lain sebagainya. Tetapi tidak banyak masyarakat yang menekuni bidang tersebut. Banyak juga masyarakat yang hanya memiliki keterampilan umum, sehingga hal tersebut yang membuat sebagian besar masyarakat hanya menekuni satu bidang pekerjaan. Apabila masyarakat memiliki keterampilan dan memanfaatkannya maka akan ada pendapatan tambahan dalam keluarga tersebut dan tidak hanya mengandalkan satu bidang pekerjaan, terlebih lagi pendapatan yang didapatkan di satu bidang pekerjaan kecil. Karena keterampilan dijadikan investasi modal sebagai sarana alternatif untuk memperoleh suatu pendapatan. Kurangya keterampilan dan kecilnya pendapatan juga menyebabkan masyarakat di Desa Mas-Mas bekerja keluar negeri. Dari data Kecamatan Batukliang Utara dalam angka 2018 bahwa sebanyak 173 penduduk yang bekerja ke luar negeri, dengan 144 laki-laki dan 29 perempuan. Hal tersebut dikarenakan pendapatan yang tidak sesuai dengan pengeluaran.

\section{METODE PENELITIAN}

Adapun metode dalam penelitian ini menggunakan jenis penelitian kuantitatif. Penelitian kuantitatif adalah metode penelitian yang berlandaskan pada filsapat positivisme, digunakan untuk meneliti pada populasi atau sampel tertentu, tehnik pengambilan sampel pada umumnya dilakukan secara random, pengumpulan data menggunakan insrumen penelitian, analisis data bersifat kuantitatif/statistik dengan tujuan untuk menguji hipotesis yang telah ditetapkan (Sugiono, 2012:14). Dalam penelitian ini menggunakan pendekatan diksriptif. Diksriptif adalah penelitian yang dilakukan untuk mengetahui nilai variabel mandiri (tingkat pendidikan, keterampilan, tingkat pendapatan dan 
tanggungan keluarga) baik satu variabel atau lebih (independen) tanpa membuat perbandingan dengan variabel yang lain (Sugiono, 2012: 15).

Tehnik sampling yang digunakan dalam penelitian ini menggunakan proporsional sampling, karena penelitian ini mengambil wakil dari setiap kelompok yang ada pada populasi. Berdasarkan hasil perhitungan dengan menggunakan rumus Slovin jadi jumlah sampel yang diambil dalam penelitian ini sebanyak 92 KK miskin di Desa Mas-Mas. Adapun tehnik pengumpulan data yang digunakan yakni dengan menggunakan Kuesioner dan dokumentasi. Kuisioner dalam penelitian ini akan diberikan kepada rumah tangga miskin yang ada di Desa Mas-Mas Kecamatan Batukliang Utara Kabupaten Lombok Tengah sedangkan Dokumen atau data yang diambil dari penelitian ini berupa data-data tentang jumlah kepala keluarga miskin di BPS Lombok Tengah dan profil Desa Mas-Mas Kecamatan Batukliang Utara Kabupaten Lombok Tengah.

Tehnik analisis data yang digunakan dalam penelitian ini adalah dengan analisis regresi linear berganda, Pengujian hipotesis dilakukan dengan menggunakan uji statistik, adapun langkah-langkahnya sebagai berikut:
a. Uji Simultan (Uji F)
b. Uji Parsial (Uji t)
c. Koefisien Determinasi $\left(\mathrm{R}^{2}\right)$
d. Analisis Korelasi Ganda (R)

\section{HASIL PENELITIAN DAN PEMBAHASAN}

\section{A. Hasil Penelitian}

1. Analisis Regresi Linier Berganda

Regresi linier berganda berguna untuk mengetahui pengaruh antara dua atau lebih variabel independen terhadap variabel dependen atau untuk membuktikan ada atau tidaknya hubungan fungsional antara dua variabel bebas $(\mathrm{X})$ atau lebih dengan sebuah variabel terikat (Y). Analisis linier berganda dalam penelitian ini digunakan untuk mengetahui pengaruh 
tingkat pendidikan, keterampilan, tingkat pendapatan dan tanggungan keluarga terhadap kemiskinan di Desa Mas-Mas Kecamatan Batukliang Utara Kabupaten Lombok Tengah.

Tabel 4.5 Hasil Analisis Regresi Linear Berganda

Coefficients $^{\mathrm{a}}$

\begin{tabular}{|l|r|r|r|r|r|}
\hline \multirow{2}{*}{ Model } & \multicolumn{2}{|c|}{$\begin{array}{c}\text { Unstandardized } \\
\text { Coefficients }\end{array}$} & $\begin{array}{r}\text { Standardized } \\
\text { Coefficients }\end{array}$ & & \\
\cline { 2 - 5 } & \multicolumn{1}{|c|}{$\mathrm{B}$} & Std. Error & \multicolumn{1}{|c|}{ Beta } & \multicolumn{1}{c|}{$\mathrm{t}$} & \multicolumn{1}{c|}{ Sig. } \\
\hline $1 \quad$ (Constant) & 8.756 & 3.053 & & 2.868 & .005 \\
tingkat pendidikan & .034 & .172 & .022 & .196 & .845 \\
keterampilan & .177 & .117 & .153 & 1.514 & .134 \\
tingkat pendapatan & .453 & .168 & .296 & 2.689 & .009 \\
tanggungan keluarga & -.252 & .096 & -.297 & -2.614 & .011 \\
\hline
\end{tabular}

a. Dependent Variable: kemiskinan

Persamaan regresinya sebagai berikut:

$Y=\alpha+\beta_{1} X_{1}+\beta_{2} X_{2}+\beta_{3} X_{3}+\beta_{4} X_{4}$

$\mathrm{Y}=8,756+0,034+0,177+0,453+(-0,252)$

$\mathrm{Y}=8,756+0,034+0,177+0,453-0,252$

Keterangan:

$$
\begin{array}{ll}
\mathrm{Y}=\text { Kemiskinan } & \mathrm{X} 4=\text { Tanggungan Keluarga } \\
\mathrm{X} 1=\text { Tingkat Pendidikan } & \alpha=\text { Konstanta } \\
\mathrm{X} 2=\text { Keterampilan } & \beta=\text { Koefisien } \\
\mathrm{X} 3=\text { Tingkat Pendapatan } &
\end{array}
$$

Persamaan regresi di atas dapat dijelaskan sebagai berikut: 
a. Konstanta sebesar 8,756; artinya jiaka tingkat pendidikan (X1), keterampilan (X2), tingkat pendapatan (X3) dan tanggungan keluarga (X4) nilainya adalah 0 , maka kemiskinan (Y) nilainya adalah 8,756.

b. Koefisien regresi variabel tingkat pendidikan (X1) sebesar 0,034; artinya jika variabel independen lain nilainya tetap dan tingkat pendidikan mengalami kenaikan 1\%, maka kemiskinan (Y) akan mengalami peningkatan sebesar 0,034. Koefisien bernilai positif artinya terjadi hubungan npositif antara tingkat pendidikan dengan kemiskinan, semakin tinggi tingkat pendidikan maka semakin bertambah kesejahteraan yang berarti kemiskinan akan semakin berkurang.

c. Koefisien regresi variabel keterampilan (X2) sebesar 0,177; artinya jika variabel independen lain nilainya tetap dan keterampilan mengalami kenaikan 1\%, maka kemiskinan (Y) akan mengalami peningkatan sebesar 0,177 . Koefisien bernilai positif artinya terjadi hubungan positif antara keterampilan dengan kemiskinan, semakin tinggi keterampilan maka semakin bertambah kesejateraan yang berarti kemiskinan akan semakin berkurang.

d. Koefisien regresi variabel tingkat pendapatan (X3) sebesar 0,453; artinya jika variabel independen lain nilainya tetap dan tingkat pendapatan mengalami kenaikan 1\%, maka kemiskinan (Y) akan mengalami peningkatan sebesar 0,453. Koefisien bernilai positif artinya terjadi hubungan positif antara tingkat pendapatan dengan kemiskinan, semakin tinggi tingkat pendapatan maka semakin bertambah kesejahteraan yang berarti kemiskinan semakin berkurang.

e. Koefisien regresi variabel tanggungan keluarga (X4) sebesar -0,252; artinya jika variabel independen lain nilainya tetap dan tanggungan keluarga mengalami kenaikan 1\%, maka kemiskinan (Y) akan mengalami penurunan sebesar 0,252. Koefisien bernilai negatif artinya terjadi hubungan negatif antara tanggungan keluarga dengan 
kemiskinan, semakin tinggi tanggungan keluarga maka semakin berkurang kesejahteraan yang berarti kemiskinan semakin bertambah.

\section{Uji Statistik}

a. Uji Simultan (Uji F)

Uji $\mathrm{F}$ digunakan untuk mengetahui pengaruh semua variabel independen yang dimaksudkan dalam model regresi secara bersamasama terhadap variabel dependen yang diuji pada tingkat signifikansi 0,05.berdasarkan hasil pengujian dengan perhitungan analisis regresi menggunakan program komputer SPSS 16.0, hasil uji F dapat dilihat pada tabel berikut:

Tabel 4.7 Hasil Uji Secara Simultan (Uji F)

ANOVA $^{b}$

\begin{tabular}{|l|r|r|r|r|r|}
\hline \multicolumn{1}{|l|}{ Model } & Sum of Squares & df & Mean Square & F & Sig. \\
\hline 1 Regression & 53.761 & 4 & 13.440 & 3.475 & $.011^{\mathrm{a}}$ \\
Residual & 336.456 & 87 & 3.867 & & \\
Total & 390.217 & 91 & & & \\
\hline
\end{tabular}

a. Predictors: (Constant), tanggungan keluarga, keterampilan, tingkat pendapatan, tingkat pendidikan

b. Dependent Variable: kemiskinan

Berdasarkan tabel di atas, diperoleh nilai $F_{\text {hitung }}$ sebesar 3,475 dengan nilai signifikansinya 0,011 karena nilai $F_{\text {hitung }}>F_{\text {tabel }}(3,475>$ 2,48 ) dan nilai signifikansinya jauh lebih kecil dari 0,05 , maka model regresi dapat digunakan untuk memprediksi kemiskinan atau dapat dikatakan bahwa tingkat pendidikan, keterampilan, tingkat pendapatan dan tanggungan keluarga secara bersama-sama berpengauh terhadap kemiskinan.

b. Uji Parsial (Uji t) 
Pengujian hipotesis secara parsial ini dimaksud untuk menguji seberapa besar pengaruh dari masing-masing variabel bebas yaitu tingkat pendidikan (X1), keterampilan (X2), tingkat pendapatan (X3) dan tanggungan keluarga (X4) terhadap kemiskinan (Y). Hasil uji t dapat dilihat padatabel di bawah ini:

Tabel 4.6 Hasil Uji Secara Parsial (Uji t)

\section{Coefficients $^{\mathbf{a}}$}

\begin{tabular}{|l|r|r|r|r|r|}
\hline \multirow{2}{*}{ Model } & \multicolumn{2}{|c|}{$\begin{array}{c}\text { Unstandardized } \\
\text { Coefficients }\end{array}$} & $\begin{array}{r}\text { Standardized } \\
\text { Coefficients }\end{array}$ & & \\
\cline { 2 - 6 } & \multicolumn{1}{|c|}{$\mathrm{B}$} & Std. Error & \multicolumn{1}{c|}{ Beta } & \multicolumn{1}{c|}{$\mathrm{T}$} & Sig. \\
\hline 1 (Constant) & 8.756 & 3.053 & & 2.868 & .005 \\
tingkat pendidikan & .034 & .172 & .022 & .196 & .845 \\
keterampilan & .177 & .117 & .153 & 1.514 & .134 \\
tingkat pendapatan & .453 & .168 & .296 & 2.689 & .009 \\
tanggungan keluarga & -.252 & .096 & -.297 & -2.614 & .011 \\
\hline
\end{tabular}

a. Dependent Variable: kemiskinan

Hasil pengujian variabel independen (tingkat pendidikan, keterampilan, tingkat pendapatan dan tanggungan keluarga), dan hasil pengujian dari masing-masing indikator variabel independen secara parsial atau individu yang dilakukan dengan uji $\mathrm{t}$ adalah sebagai berikut:

1) Tingkat Pendidikan

H0: Tidak ada pengaruh tingkat pendidikan terhadap kemiskinan di Desa Mas-Mas Kecamatan Batukliang Utara Kabupaten Lombok Tengah. 
Ha: Ada pengaruh tingkat pendidikan terhadap kemiskinan di Desa Mas-Mas Kecamatan Batukliang Utara Kabupaten Lombok Tengah.

Berdasarkan tabel di atas hasil perhitungan dengan menggunakan SPSS 16.0, dapat diketahui bahwa variabel tingkat pendidikan mempunyai nilai $\mathrm{t}_{\text {hitung }}<\mathrm{t}_{\text {tabel }}(0,196<1,98)$ dan memiliki nilai signifikan 0,845 jauh lebih besar dari 0,05. Artinya variabel tingkat pendidikan tidak memiliki pengaruh yang signifikan terhadap kemiskinan. Dapat disimpulkan bahwa H0 diterima dan Ha ditolak.

2) Keterampilan

H0: Tidak ada pengaruh keterampilan terhadap kemiskinan di Desa Mas-Mas Kecamatan Batukliang Utara Kabupaten Lombok Tengah.

Ha: Ada pengaruh keterampilan terhadap kemiskinan di Desa Mas-Mas Kecamatan Batukliang Utara Kabupaten Lombok

Tengah.

Berdasarkan tabel di atas hasil perhitungan dengan menggunakan SPSS 16.0, dapat diketahui variabel keterampian mempunyai nilai thitung $<\mathrm{t}_{\text {tabel }}(1,514<1,98)$ dan memiliki nilai signifikan 0,134 jauh lebih besar dari 0,05. Artinya variabel keterampilan tidak memiliki pengaruh yang signifikan terhadap kemiskinan. Dapat disimpulkan bahwa Ha ditolak dan H0 diterima.

3) Tingkat Pendapatan

H0: Tidak ada pengaruh tingkat pendapatan terhadap kemiskinan di Desa Mas-Mas Kecamatan Batukliang Utara Kabupaten Lombok Tengah.

Ha: Ada pengaruh tingkat pendapatan terhadap kemiskinan di Desa Mas-Mas Kecamatan Batukliang Utara Kabupaten Lombok Tengah. 
Berdasarkan tabel di atas hasil perhitungan dengan menggunakan SPSS 16.0, dapat diketahui variabel tingkat pendapatan mempunyai nilai $t_{\text {hitung }}>\mathrm{t}_{\text {tabel }}(2,689>1,98)$ dan memiliki nilai signifikan 0,009 jauh lebih kecil dari 0,05. Artinya variabel tingkat pendapatan memiliki pengaruh yang positif dan signifikan terhadap kemiskinan. Dapat disimpulkan bahwa $\mathrm{Ha}$ diterima dan $\mathrm{H} 0$ ditolak.

4) Tanggungan Keluarga

H0: Tidak ada pengaruh tanggungan keluarga terhadap kemiskinan di Desa Mas-Mas Kecamatan Batukliang Utara Kabupaten Lombok Tengah.

Ha: Ada pengaruh tanggungan keluarga terhadap kemiskinan di Desa Mas-Mas Kecamatan Batukliang Utara Kabupaten Lombok Tengah.

Berdasarkan tabel di atas hasil perhitungan dengan menggunakan SPSS 16.0, dapat diketahui variabel tanggungan keluarga mempunyai nilai $-t_{\text {hitung }}>-t_{\text {tabel }}(-2,614>-1,98)$ dan memiliki nilai signifikan 0,011 jauh lebih kecil dari 0,05 . Artinya variabel tanggungan keluarga memiliki pengaruh yang negatif dan signifikan terhadap kemiskinan. Dapat disimpulkan bahwa H0 ditolak dan Ha diterima.

c. Koefisien Determinasi $\left(\mathrm{R}^{2}\right)$

Koefisien determinasi bertujuan untuk mengetahui seberapa besar kemampuan variabel independen menjelaskan variabel dependen. Hasil uji koefisien determinasi dapat dilihat pada tabel dibawah ini:

Tabel 4.8 Nilai Koefisien Determinasi $\left(\mathrm{R}^{2}\right)$ 
Model Summary

\begin{tabular}{|l|r|r|r|r|}
\hline Model & \multicolumn{1}{|c|}{$\mathrm{R}$} & R Square & \multicolumn{1}{c|}{$\begin{array}{c}\text { Adjusted R } \\
\text { Square }\end{array}$} & $\begin{array}{r}\text { Std. Error of } \\
\text { the Estimate }\end{array}$ \\
\hline 1 & $.371^{\mathrm{a}}$ & .138 & .098 & 1.967 \\
\hline
\end{tabular}

a. Predictors: (Constant), tanggungan keluarga, keterampilan, tingkat pendapatan, tingkat pendidikan

Berdasarkan tabel di atas dapat dilihat bahwa nilai koefisien determinasi $\left(\mathrm{R}^{2}\right)$ sebesar 0,138 hal ini berarti $13,8 \%$ variabel dependen Kemiskinan dapat dijelaskan oleh variabel independen tingkat pendidikan, keterampilan, tingkat pendapatan dan tanggungan keluarga. Sedangkan sisanya 86,2\% dijelaskan oleh variabel lain yang tidak termasuk dalam analisis regresi ini.

d. Analisis Korelasi Ganda (R)

Korelasi ganda bertujuan untuk mengetahui hubungan yang terjadi antara dua atau lebih variabel independen (tingkat pendidikan, keterampilan, tingkat pendapatan, dan tanggungan keluarga) terhadap variabel dependen (Kemiskinan) secara serentak.

Berdasarkan tabel 4.8 diperoleh angka $\mathrm{R}$ sebesar 0,371. Hal ini menjukkan bahwa terjadi hubungan yang rendah antara tingkat pendidikan, keterampilan, tingkat pendapatan dan tanggungan keluarga terhadap kemiskinan.

\section{B. Pembahasan}

Berdasarkan keterangan dan perumusan hipotesis yang telah dilakukan dalam penelitian yang diperoleh melalui analisis secara kuantitatif dengan perhitungan melalui SPSS 16.0. Maka rumusan hipotesis yang diajukan dalam penelitian ini adalah sebagai berikut:

1. Pengaruh Secara Simultan 
Dari keempat variabel independen yaitu tingkat pendidikan, keterampilan, tingkat pendapatan dan tanggungan keluarga berpengaruh secara simultan, hal ini ditunjukkan dengan uji $\mathrm{F}$ yang memiliki nilai signifikansi lebih kecil dari 0,05 yaitu sebesar 0,011 dengan nilai $F_{h i t u n g}>$ $F_{\text {tabel }}(3,475>2,48)$. Sehingga dapat disimpulkan bahwa variabel tingkat pendidikan, keterampilan, tingkat pendapatan dan tanggungan keluarga secara bersama-sama berpengaruh terhadap kemiskinan di Desa Mas-Mas pada tahun 2019.

Hasil penelitian ini memperkuat teori (Todaro:2000) yang menyatakan bahwa faktor-faktor penyebab kemiskinan terutama yang ada di pedesaan diantaranya sempitnya lahan pertanian yang mereka miliki ataupun tidak produktifnya lagi lahan yang dimiliki, rendahnya tingkat pendidikan sehingga berakibat pada rendahnya tingkat pengetahuan dan produktifitas dalam mengelola usaha taninya, tidak ada pekerjaan sampingan, pendapatan yang tidak menentu sebagai akibat usaha yang sangat tergantung dengan musim

Hasil ini juga didukung oleh penelitian yang dilakukan oleh Ibnu Abdi Maulana (2013) yang menyatakan bahwa variabel bebas keterampilan, jumlah tanggungan keluarga, pendapatan, dan pendidikan secara bersama-sama mempunyai pengaruh yang signifikan terhadap variabel keluarga miskin.

2. Pengaruh Secara Parsial

a. Pengaruh Tingkat Pendidikan Terhadap Kemiskinan

Hasil penelitian secara parsial diketahui dari hasil uji t yaitu sebesar 0,196 dan memiliki nilai signifikansi sebesar 0,845 > taraf sifnifikansi 0,05, maka H0 diterima dan Ha ditolak. Artinya bahwa tingkat pendidikan tidak memiliki pengaruh yang signifikan terhadap kemiskinan. Jadi dari kasus ini dapat disimpulkan bahwa secara parsial tingkat pendidikan tidak berpengaruh terhadap kemiskinan di Desa Mas-Mas. 
Hasil penelitian ini memperkuat teori (Eka Agustina $d k k, 2018$ ) yang menyatakan bahwa tingkat pendidikan belum mampu menurunkan kemiskinan. hal tersebut disebabkan oleh beberapa hal. Pertama, mayoritas masyarakat yang bekerja di sektor pertanian tidak ditentukan berdasarkan pendidikan atau kemampuan melek hurup. Kedua, kurangnya kemampuan dan keahlian tertentu untuk bersaing dalam mencari pekerjaan yang lebih baik. Jadi tidak cukup dengan berbekal melek huruf mereka dapat terhindar dari kemiskinan.

Hasil penelitian ini didukung oleh penelitian yang dilakukan oleh Abdi Maulana (2013), yang menyatakan bahwa tingkat pendidikan tidak memiliki pengaruh terhadap kemiskinan. Tetapi tidak dengan penelitian yang dilakukan oleh Pande Putu Erwin Adiana dan Ni Luh Karmini (2012) dan Arya Dwiandana Putri dan Nyoman Djinar Setiawan (2013) yang menyatakan bahwa pendidikan berpengaruh positif dan signifikan terhadap kemiskinan.

b. Pengaruh Keterampilan Terhadap Kemiskinan

Hasil penelitian secara parsial diketahui dari hasil uji t yaitu sebesar 1,514 dan memiliki nilai signifikansi sebesar 0,134 > taraf sifnifikansi 0,05, maka H0 diterima dan Ha ditolak. Artinya bahwa keterampilan tidak memiliki pengaruh yang signifikan terhadap kemiskinan. Jadi dari kasus ini dapat disimpulkan bahwa secara parsial keterampilan tidak berpengaruh terhadap kemiskinan di Desa Mas-Mas.

Tidak ada teori yang memperkuat hasil penelitian ini karena keterampilan yang ada di Desa Mas-Mas adalah keterampilan secara umum atau dapat diartikan bahwa keterampilan umum ini dimiliki oleh semua orang dan sudah menjadi hal yang lumrah. Sedangkan keterampilan khusus hanya dimiliki oleh sebagian kecil rumah tangga miskin di Desa Mas-Mas. Sehingga menyebabkan keterampilan tidak berpengaruh terhadap kemiskinan. 
Hasil penelitian ini tidak didukung oleh penelitian yang dilakukan oleh Abdi Maulana (2013) yang menyatakan bahwa keterampian berpengaruh positif dan signifikan terhadap kemiskinan.

c. Pengaruh Tingkat Pendapatan Terhadap Kemiskinan

Hasil penelitian secara parsial diketahui dari hasil uji t yaitu sebesar 2,689 dan memiliki nilai signifikansi sebesar $0,009<\operatorname{taraf}$ sifnifikansi 0,05, maka H0 ditolak dan Ha diterima. Artinya bahwa tingkat pendapatan memiliki pengaruh yang positif dan signifikan terhadap kemiskinan. Jadi dari kasus ini dapat disimpulkan bahwa secara parsial tingkat pendapatan berpengaruh positif terhadap kemiskinan di Desa Mas-Mas.

Hasil penelitian ini memperkuat teori (Samuelson dalam Wahyu:2017) yang menyatakan bahwa pendapatan rumah tangga sangat besar pengaruhnya terhadap tingkat konsumsi. Semakin baik tingkat pendapatan, semakin baik pula tingkat konsumsi. Karena tingkat pendapatan meningkat, kemampuan rumah tangga untuk membeli aneka kebutuhan konsumsi menjadi semakin besar.

Hasil ini juga didukung oleh penelitian yang dilakukan oleh Pande Putu Erwin Adiana dan Ni Luh Karmini (2012) dan Ibnu Abdi Maulana (2013) yang sama-sama menyatakan bahwa pendapatan berpengaruh positif dan signifikan terhadap rumah tangga kemiskinan.

d. Pengaruh Tanggungan Keluarga Terhadap Kemiskinan

Hasil penelitian secara parsial diketahui dari hasil uji t yaitu sebesar -2,614 dan memiliki nilai signifikansi sebesar 0,011 < taraf sifnifikansi 0,05, maka H0 ditolak dan Ha diterima. Artinya bahwa tanggungan keluarga memiliki pengaruh yang negatif dan signifikan terhadap kemiskinan. Jadi dari kasus ini dapat disimpulkan bahwa secara parsial tanggungan keluarga berpengaruh negatif terhadap kemiskinan di Desa Mas-Mas. 
Hasil penelitian ini memperkuat teori (Rivani dalam Nanang:2016) yang menyatakan bahwa Semakin besar jumlah anggota keluarga maka akan semakin besar pendapatan yang dikeluarkan untuk biaya hidup. Jumlah anggota keluarga yang banyak akan mengakibatkan kondisi akan menjadi miskin.

Hasil ini juga didukung oleh penelitian yang dilakukan oleh Abdi Maulana (2013) yang menyatakan bahwa tanggungan keluaga berpengaruh negatif dan signifikan terhadap kemiskinan. Tetapi tidak dengan penelitian yang dilakukan oleh Pande Putu Erwin Adiana dan Ni Luh Karmini (2012) menyatakan bahwa tanggungan keluarga berpengaruh positif dan signifikan terhadap pola konsumsi rumah tangga miskin.

\section{KESIMPULAN}

Berdasarkan hasil penelitian dan analisis data tentang pengaruh tingkat pendidikan, keterampilan, tingkat pendapatan dan tanggungan keluarga terhadap kemiskinan, maka dapat diambil beberapa kesimpulan sebagai jawaban atas pokok permasalahan yang diajukan dalam penelitian ini yaitu:

Secara simulltan, pengaruh tingkat pendidikan, keterampilan, tingkat pendapatan dan tanggungan keluarga berpengaruh secara simultan atau bersamasama terhadap kemiskinan di Desa Mas-Mas. Hal ini terbukti dari nilai $F_{\text {hitung }}>F_{\text {tabel }}$ $(3,475>2,48)$. Besarnya pengaruh keempat variabel terhadap kemiskinan di Desa Mas-Mas ditunjukkan dengan $R$ Square yaitu sebesar 0,138 atau 13,8\% dan sisanya $86,2 \%$ depengaruhi oleh variabel lain yang tidak termasuk dalam penelitian ini. Korelasi ganda secara serentak menunjukkan bahwa terjadi hubungan yang rendah antara tingkat pendidikan, keterampilan, tingkat pendapatan dan tanggungan keluarga terhadap kemiskinan di Desa Mas-Mas Kecamatan Batukliang Utara Kabupaten Lombok Tengah pada tahun 2019.

Secara parsial, variabel tingkat pendidikan dan keterampilan tidak memiliki pengaruh yang signifikan terhadap kemiskinan di Desa Mas-Mas. Hal tersebut dapat dilihat dari nilai $\mathrm{t}_{\text {hitung }}<\mathrm{t}_{\text {tabel }} \quad(0,196<1,98$ dan $1,514<1,98)$. Sedangkan 
variabel tingkat pendapatan memiliki pengaruh yang positif dan signifikan terhadap kemiskinan di Desa Mas-Mas. Hal tersebut dapat dilihat dari nilai thitung $>$ $t_{\text {tabel }}(2,689>1,98)$ dan begitupun dengan variabel tanggungan keluarga memiliki pengaruh yang negatif dan signifikan terhadap kemiskinan di Desa Mas-Mas. Hal tersebut dapat dilihat dari nilai - $\mathrm{t}_{\text {hitung }}>-\mathrm{t}_{\text {tabel }}(-2,614>-1,98)$.

\section{DAFTAR RUJUKAN}

Abdullah Boedi, Saebani Ahmad. (2014). Metode Penelitian Ekonomi Islam (Muamalah). Bandung: CV.Pustaka Setia.

Arya Dwiandana Putri dan Nyoman Djinar Stiawina. (2013). Pengaruh Umur, Pendidikan, Pekerjaan Terhadap Pendapatan Rumah Tangga Miskin di Desa Bebandem. Jurnal Ekonomi Pembangunan Universitas Udayana. Vol. 2, No. 4.

Badan Pusat Statistik (BPS). (2019). Kecamatan Batukliang Utara dalam Angka 2018. Katalog BPS 1102001.5202091 diiunduh di https://lomboktengahkab.bps.go.id diakses tanggal 26 Maret 2019.

. (2017). Garis Kemiskinan dan Penduduk Miskin di Kabupaten Lombok Tengah. Lombok Tengah: BPS

. (2018). Data dan Informasi Kemiskinan Provinsi Nusa Tenggara Barat 2013-2017. Diiunduh di https://ntb.bps.go.id diakses tanggal 26 Maret 2019.

Bambang Setiaji. (2019). http://bambangsitiaji.blogspot.com/2019/pengertianbakat-macam-macam-jenis-dan-contoh-bakat.html. Diakses tanggal 18 april 2019.

Eka Agustina, Mohd. Nur Syechalad, Abubakar Hamzah. (2018). Pengaruh Jumlah Penduduk, Tingkat Pengangguran dan Tingkat Pendidikan Terhadap Kemiskinan di Provinsi Aceh. Jurnal Perspektif Ekonomi Darussalam. Vol. 4, No.2.

Hidayat Wahyu. (2017). Perencanaan Pembangunan Daerah Menggunakan Pendekatan Pertumbuhan Ekonomi, Disparitas Pendapatan dan Kemiskinan. Malang: UMM PRESS.

Ibnu Abdi Maulana. (2013). Analisis Pengaruh Keterampilan, Jumlah Tanggungan Keluarga, Pendapatan dan Pendidikan Terhadap Keluarga Miskin di Desa Sumbergondo Kecamatan Glenmore Kabupaten Banyuwangi. Skripsi dipublikasikan. Jember: Jurusan Ilmu Ekonomi dan Studi Pembangunan Fakultas Ekonomi Universitas Jember. 
Kasim Muslim. (2006). Karakteristik Kemiskinan \& Strategi Penanggulangannya. Yogyakarta: PT Indomedia Global.

Kunawangsih Tri, Antyo. (2006). Aspek Dasar Ekonomi Mikro. Jakarta: PT Grasindo.

Kusfiardi. (2018). http://www.alinea.id/kolom/mengukur-tingkat-kemiskinanb1U5M9dVe. Diakses tanggal 25 April 2019.

Maha Neni. (2016). http://mahaneni.blogspot.com/2016/06/pengertian-indikatordan-penyebab.html. Diakses tanggal 30 Maret 2019.

Martono Nanang. (2016). Sosiologi Perubahan Sosial. Cetakan ke-4. Jakarta: Fajat Interpratama Mandiri.

Pande Putu Erwin Adiana dan Ni Luh Karmini. Pengaruh Pendapatan, Jumlah Anggota Keluarga dan Pendidikan Terhadap Pola Konsumsi Rumah Tangga Miskin di Kecamatan Gianyar. Jurnal Ekonomi Pembangunan Fakultas Ekonomi Universitas Udayana. Hal.39-48

Sugianto Catur. (2002). Ekonometrika Terapan. Yogyakarta: BPFE-Yogyakarta

Sugiono. (2012). Metode Penelitian Kuantitatif dan Kualitatif dan $R \& D$. Bandung: Alfabeta (2014). Metode Penelitian Kuantitatif dan Kualitatif dan R \& D. Bandung: Alfabeta

Sukardi. (2012). Metodologi Penelitian Pendidikan. Cetakan ke-9. Jakarta: Sinar Grafika Offset.

Sukirno Sadono. (2010). Mikro Ekonomi Teori Pengantar. Jakarta: Raja Grafindo Persada.

Todaro, Michael, P. (2000). Pembangunan Ekonomi di Dunia Ketiga. Cetakan ke7 (diterjemah oleh Haris Munandar). Erlangga: Jakarta.

Undang-Undang No. 20 Tahun 2003 Tentang Sistem Pendidikan Nasional.

Usman Sunyonto. (2010). Pembangunan dan Pemberdayaan Masyarakat. Cetakan ke-6. Yogyakarta: Pustaka Pelajar.

Wibowo agus. (2013). Akuntabilitas Pendidikan. Yogyakarta: Pustaka Pelajar

Wirgadinata Wildana. (2011). Islam dan Pengentasan Kemiskinan. Malang: UINMaliki Press

Zuriah Nurul. (2009). Metodologi Penelitian Sosial dan Pendidikan. Cetakan ke-3. Jakarta: Sinar Grafika Offset 